\title{
“What I Believe Can Rescue That Nation": Diaspora Working to Transform Education in Fragility and Conflict
}

\section{Citation}

Dryden-Peterson, Sarah and Celia Reddick (2019). "What I Believe Can Rescue That Nation": Diaspora Working to Transform Education in Fragility and Conflict. Comparative Education Review 63, no. 2: 213-235.

\section{Permanent link}

http://nrs.harvard.edu/urn-3:HUL.InstRepos:41343891

\section{Terms of Use}

This article was downloaded from Harvard University's DASH repository, and is made available under the terms and conditions applicable to Open Access Policy Articles, as set forth at http:// nrs.harvard.edu/urn-3:HUL.InstRepos:dash.current.terms-of-use\#OAP

\section{Share Your Story}

The Harvard community has made this article openly available. Please share how this access benefits you. Submit a story. 


\title{
Title: \\ 'What I believe can rescue that nation': Diaspora Working to Transform Education in Fragility and Conflict
}

\section{Short title: Diaspora Transform Education in Fragility and Conflict}

\author{
Sarah Dryden-Peterson and Celia Reddick \\ Harvard Graduate School of Education
}

\begin{abstract}
Acknowledgements
We are grateful to the women and men who participated in this study, who shared their ideas with us and shaped ours; to Irene Liefshitz, whose insights and care as an interviewer and co-thinker have deeply shaped and strengthened this work; and to Sara Lawrence-Lightfoot, Paola Uccelli, Lesley Bartlett, and Heather Hill, whose generous feedback on earlier iterations sharpened our arguments and writing.
\end{abstract}

\section{Funding}

Our work was generously funded by the Harvard University Milton Fund, the Social Sciences and Humanities Research Council of Canada, and the National Academy of Education/ Spencer Foundation.

\section{Research Ethics}

All research drawn upon in this article was approved by the Committee on the Use of Human Subjects at Harvard University. All participants were aware of our roles as academic researchers and consented to the research after clear explanations of its potential risks and benefits, and their rights.

\section{Author Bios}

SARAH DRYDEN-PETERSON (sarah_dryden-peterson@gse.harvard.edu) is an Associate Professor at the Harvard Graduate School of Education. Her research and teaching focus on education in conflict and postconflict settings, particularly the role education plays in building peaceful, participatory societies and enabling young people and their families to build envisioned futures in the midst of uncertainty.

CELIA REDDICK (creddick@g.harvard.edu) is a PhD candidate at the Harvard Graduate School of Education. Her research explores the intersection of education and migration, with a focus on educational policies and practices that support children's and families' wellbeing in settings of displacement. Celia is a former Editor and Co-Chair of the Harvard Educational Review. 


\section{'What I believe can rescue that nation': \\ Diaspora Working to Transform Education in Fragility and Conflict}

\section{Introduction}

Mohammed Kharoti ${ }^{1}$ believes that education, more than money, is a tool for peace in Afghanistan. Born to what he called "a nomadic family," as an eleven-year-old, Kharoti enrolled himself in primary school and "found this great treasure of education from my childhood that I can never forget." In our interview with him, he reflected that his own educational experiences have in turn motivated him, now as a member of diaspora living in the United States, to work on educational development in his country of origin. He started a school in 2001 in an area of Helmand Province that had no schools and where he said he could "not find one woman who can read or write." The school, which is free and follows the government curriculum, had over 1,200 students at the time of our interview.

Fragility and conflict, like Kharoti experienced as a child in Afghanistan, are associated with limited educational opportunities. Fragile settings are characterized by weak governance and limited public infrastructure, as well as extreme inequality; in fragile settings, governments are often unable or unwilling to provide public services, including education, especially to the most marginalized. While only $9 \%$ of the world's population live in settings of fragility, over $50 \%$ of out-of-school children globally do (UNHCR and Global Monitoring Report 2016). Conflict similarly undermines education, not only through nation-states' limited ability to provide schooling but also through destruction of educational facilities and death and displacement of teachers. In conflict- 
affected settings, only $65 \%$ of children reach the end of primary school, with children in rural areas, girls, and ethnic and linguistic minorities up to three times less likely to do so (UNESCO, 2011). Now in his 70s, Kharoti is preoccupied by on-going fragility in his country of origin. Indeed, nation-states that have previously experienced conflict often relapse into conflict or experience protracted fragility, especially in situations where postconflict development has not transformed underlying conflict dynamics, instead reinforcing status quo inequalities, as in Guatemala (Bellino 2017), Sierra Leone (Novelli and Higgins 2017), and South Africa (Christie 2016). Given these challenges to education in fragile and conflict-affected settings (FCS), diaspora members, like Kharoti, may be important actors in education development who can uniquely contribute to long-term goals of peace and stability in their countries of origin.

Diaspora often maintain flows of resources and communication with countries of origin through remittances, business creation, political engagement, and personal relationships. In these transnational activities, they are positioned as entrepreneurs and as cultural brokers in their country of origin, with implications both for family-level poverty reduction as well as institutional transformation in economic, social, and political domains (Van Hear 2011, Brinkerhoff 2016, Portes and Sensenbrenner 2003, Levitt 1998). Within FCS, diaspora are also increasingly positioned as development actors, particularly as connected to private sector investment, poverty alleviation, and replacement social service provision made necessary by fragility and conflict and/or reductions in foreign assistance (Glick Schiller 2011, World Bank 2011, 167, United Nations General Assembly 2016, 23, Van Hear 2011). Existing research suggests that even development-oriented diaspora engagement in FCS, as elsewhere, has tended 
toward being privately-oriented rather than toward "broad societal renewal" (Van Hear 2014b).

Our research, on the other hand, demonstrates that diaspora-led education development is distinct from both status quo international education development, which often reinforces inequalities, and diaspora-led development in other sectors, which is often privately-oriented. We find that in the education sector, diaspora in FCS engage in work that is publicly-oriented and aimed toward systematic transformation of the content and opportunity structures of education. In particular, we find that diaspora-led education development work seeks to transform conflict dynamics, through addressing historical inequalities and persistent drivers of conflict.

In this article, we seek to explain why and how fragility- and conflict-induced diaspora take this publicly-oriented and conflict-transformation approach to their development work in education. To do so, we analyze an original dataset of semistructured, in-depth interviews with 28 individuals who left Afghanistan, Haiti, South Sudan, and Zimbabwe; who settled in the United States; and who are engaged in education development work in their countries of origin. We explore how their motivations for engagement, the nature and content of the activities they pursue, and the relationship and state-level factors that enable and constrain their work interconnect to explain their particular forms of engagement in education development.

Echoing other literature, we find that identity-factors and embeddedness in both a country of origin and a country of exile shape their engagement (e.g., Nielsen and Riddle 2009, Horst 2006, Levitt and Jaworsky 2007). We find that these identity-factors link diaspora to a sense of responsibility not only to individuals but to an imagined 
community (Anderson 1991, Van Hear 2014a) and also shape knowledge of and attention to conflict dynamics that is substantively different from the approaches of status quo international education development actors. Yet, at the same time, we find that diaspora's education activities also replicate international development power structures in funding and knowledge transfer from North to South, as they use their status as both insiders and outsiders to marshal resources and claim rights to act on the responsibilities they feel to imagined communities. These tensions appear most saliently in the ways in which diaspora negotiate relationships with authorities, communities, and outside actors, drawing our attention to often-overlooked relational aspects of education development. Our findings have implications for both policy and practice that seek to foster education that breaks persistent cycles of conflict rather than reinforces them.

\section{Diaspora Engagement in Education Development in FCS}

Power imbalances are endemic to international education development, including the use of education as a tool of colonial domination and control (Burde 2014, King 2014) and neocolonialism such as aid tied to market or antiterrorism interests (Takayama, Sriprakash, and Connell 2017). Even when oriented toward "partnership," "participation," and attempts to locate authority with national governments and/or local communities (OECD-DAC 2007, King 2013), power asymmetries often remain, particularly as related to decision-making about programs and funding (Menashy 2017).

These power dynamics are particularly evident in FCS (Duffield 2001, Novelli 2016), where "expert" authority dominates (Barnett 2013). In contexts where governance and professions have been decimated by fragility and conflict, these "experts" are often, 
although not always, outsiders to the nation-state. They include donor, UN agency, and international non-governmental organization (NGO) staff, who are often culturallydistant from recipient communities and can have transient rather than long-term interests in transforming conflict dynamics (Piper 2016, Menashy 2017, Watkins 2012). This location of power is particularly troublesome in education, as education development that does not consider root causes of divisions may perpetuate, rather than mitigate, fragility and conflict (Davies 2011, Burde 2014, King 2014).

Diaspora may engage in education development for reasons that diverge from those of international development actors. Diaspora engagement in businesses, for example, is driven not only by financial returns but also emotional and social status returns, connected to personal and identity-based attachments (Nielsen and Riddle 2009, Iskander 2010). Diaspora may also hold particularly strong commitments to and shared identity with those who remained behind in precarious situations (Lyons 2007, Brinkerhoff 2011). Brinkerhoff (2016) argues that these orientations make diaspora more likely to espouse Sen's view of development (1999) as beyond "having more" to also include "being more." These orientations have implications for the choices diaspora make about the nature of their engagement in education.

Diaspora embody a "having more" view of development when they engage for economic self-benefit or when they engage in what Van Hear (2014a) calls the "household/extended family" sphere, through remittances that allow extended families to sustain themselves. This type of remittance is ubiquitous, including in FCS, and families often use them for school fees and other education-related expenses (Edwards and Ureta 2003, Lu and Treiman 2011). Every participant in our sample sent person-to-person 
remittances within the household/extended family sphere; this sphere of engagement is not the focus of this article.

Diaspora embody "being more" development when they participate in the other spheres Van Hear (2014a) identifies: "known community" or "imagined community." The "known community" involves connections that are one step removed from the family, embodying ties “among people one knows or knows of" (Van Hear 2014a, 182). An example of an education activity in this sphere is donations to homeland associations involved in school reconstruction to benefit an entire community, not only individual family members. The "imagined community" sphere invokes Anderson's conception of the nation (1991), which exists even in the absence of personal relationships between individuals. For diaspora, this sphere of engagement involves political participation or advocacy, often with goals of social or political transformation (e.g., Levitt and Jaworsky 2007, Wood 2008), yet it has not been explored vis-à-vis education. This sphere of diaspora engagement can be challenging in FCS, given priority on immediate survival needs, constraints on social mobilization, and weakness of or antagonism with national authorities (Van Hear 2014a).

Diaspora work in the known and imagined community spheres can be categorized as philanthropy or as development. Philanthropy relies on corporate and family funding, including in the form of new philanthropy 'phylantrepreneurs' (Marinucci, 2007 in Ball and Olmedo 2011) who synthesize traditional foundation models with venture capital. While increasingly blurry in terms of its non-profit vs. for-profit orientation and engagement with governments, philanthropy generally finances projects and programs operated by others, often through NGOs (Srivastava and Oh 2010, Ball and Olmedo 
2011). Development encapsulates a wider variety of public, civil society, and private actors and activities focused on the "doing" of education work, beyond the provision of funding for it. While there are conflict-affected diaspora philanthropists working in the education sector (e.g., George Soros or the Asfari Foundation), we focus here on diaspora who are engaged not in the philanthropy of funding education work but in the development of doing education work (see Table 1 for the kinds of work in which our participants engage).

In addition to their personal and identity-based attachments to the country of origin, diaspora actors may engage differently in education than international development actors given their simultaneous embeddedness in both that country of origin and a country of exile (e.g., Fox 2005, Levitt and Jaworsky 2007, Smith 2005). Brinkerhoff argues that this embeddedness is an "in between advantage" in institutional change in countries of origin, particularly when diaspora act as entrepreneurs who "visualize and capitalize on the connections between resources and opportunities" (2016, 1). This conceptualization echoes other literature that positions diaspora as "mediators" (Van Hear 2011, Smith 2005, Faist and Fauser 2011), able to be intermediaries between actors 'from above,' such as international development agencies and international NGOs, and actors 'from below,' such as students and their families. Kharoti, for example, was a retired physician who split his time geographically between Helmand Province, Afghanistan and Oregon, U.S. He was motivated to work in education development in Afghanistan, he said, by his feelings of being "very close to the people, I feel very close to the country, to the society." At the same time, he became able to work in Afghanistan after establishing an embeddedness in the U.S., where he raised his children, continued to 
live part time, and from where he drew on material resources, knowledge, and power that supported his work. Important for their education development work is that this rootedness in multiple sites enables diaspora like Kharoti to claim rights and marshal and distribute resources in order to act on their felt identity-based responsibilities both within and across national borders.

Diaspora who are embedded through their identities and also through legal citizenship status and economic stability are more likely to be active in their countries of origin (Sarabia 2011, Cohen 2011, Mügge 2012). For example, the rights to work and to accumulate capital in the country of exile can influence financial and professional resources that diaspora marshal toward education development in their country of origin. ${ }^{2}$ Further, we expect the extent to which the rights to be socially and politically active are formally recognized (see Bloemraad and Sheares 2017) would constrain diaspora's abilities to engage in education development, particularly in FCS where recognition can be tenuous (Hovil 2016).

Diaspora's positioning in relation to the country of origin can indeed influence the extent and nature of engagement (e.g., Ong 1999). For example, diaspora from FCS, who frequently left their countries of origin by force rather than by choice, may have strained relationships with authorities and institutions (Brinkerhoff 2011, Pasura 2012, Mügge 2012). They may also encounter ascription, by authorities and by communities, of outsider identities connected to the country of exile and external "expert authority," identities which can differ from their own self-perceptions of authority rooted in identitybased connections (Purkayastha 2010, Brinkerhoff 2011). In addition, given their embeddedness in a country of exile, diaspora may knowingly or unknowingly embody 
ideas and practices, or "social remittances" (Levitt 1998, Cohen 2011), associated with the very neocolonial approaches to education development that they seek to disrupt. Diaspora do not make "either/or" choices between these identities and embeddedness, but instead they straddle and negotiate these multiple positions (Faist and Fauser 2011).

Taken together, we argue that diaspora identities and embeddedness in countries of exile and countries of origin may position them to approach education development in ways that diverge from status quo international development actors. In particular, a sense of responsibility to engage and dual embeddedness may lead diaspora to view education development as a political act, as Horst (2013) argues is the case in other types of diaspora engagement. International development actors, on the other hand, often explicitly seek to avoid engaging with political dimensions of education, instead focusing on service provision (Takayama, Sriprakash, and Connell 2017, Novelli 2016). With their unique orientation, we might expect diaspora to focus on the substance of education and power relationships within its structures and content, as connected to persistent inequalities and with aims of conflict transformation.

The few documented examples of diaspora's education work in FCS do point to efforts to transform conflict dynamics by addressing persistent inequalities: enhanced educational opportunities for women following conflict in Pakistan (Khurshid 2012), learning for employment and poverty reduction in Haiti (Carlson 2011), and education for transitional justice in Bosnia and Herzegovina (Karabegović 2017). Yet, given that educational structures, content, and pedagogy can both mitigate and exacerbate conflict (Thyne 2006, Davies 2011, Paulson 2015), we cannot assume that diaspora-led education development activities would be universally oriented toward peace and stability 
(Brinkerhoff 2011). They could forward potentially-harmful political agendas, "longdistance nationalism" (Anderson 1998), or "sinister teachings" (Sommers 2004, 40) that prioritize one group over another or reinforce existing inequalities (Lampert 2012). This is the first study, to our knowledge, that examines why and how diaspora engage in education development in settings of fragility and conflict, attending to the role of this engagement in disrupting persistent power imbalances and transforming conflict dynamics.

\section{Research Design}

Our sample of interview participants draws from four countries of origin: Afghanistan, Haiti, South Sudan, and Zimbabwe. We selected these four countries using five criteria: recent and ongoing fragility and conflict; sizeable U.S.-based diaspora in 2014 (Afghanistan: 73,386; Haiti: 628,003; South Sudan: 33,700; Zimbabwe: 19,000, (Gambino, Trevelyan, and Fitzwater 2014, U.S. Census Bureau 2014)); hospitable to education development; a regional range; and variation along dimensions we anticipated would be important to diaspora identities and embeddedness, including their abilities to activate rights and marshal resources. In Afghanistan and South Sudan, decades of acute conflict have destroyed schools, disrupted teacher training, and led to massive reductions in access to and quality of education (USAID 2017, UNICEF 2017). Consequences of past conflict contribute to ongoing fragility in education in Zimbabwe (Pswarayi and Reeler 2012). Limitations on state legitimacy and capacity also breed fragility in education, as in Haiti where less than 15\% of schools are government-run (USAID 2016). 
Despite histories of conflict and on-going fragility, at the time of the interviews, these four countries were possible sites of education development by diaspora, unlike, for example, Somalia and Syria, which would meet our other criteria. Afghanistan, Haiti, and South Sudan are all part of the G7+ coalition of fragile states, committed to working collaboratively with donors toward locally-defined reconstruction goals (Wyeth 2012); and Zimbabwe was beginning to engage with diaspora in reconstruction of its economy and public institutions (McGregor and Pasura 2010). In this way, we selected sites that had political and institutional conditions that made diaspora engagement possible in order to focus our inquiry on the substance of that engagement in education, rather than its presence or absence. Despite these similarities, each country represented different stages of post-conflict reconstruction and rebuilding, and was characterized by differences in governance that we hypothesized would be relevant for our analysis.

We identified interview participants who were actively engaged in education development work in these countries. To do so, we mapped the Afghanistan, Haiti, South Sudan, and Zimbabwe U.S.-based diasporas involved in education work. We conducted English-language internet searches for educational initiatives in the four countries and investigated diaspora connections, and we established Facebook and LinkedIn pages to connect with relevant individuals and organizations. From this mapping, we surveyed 42 individuals, 52 organizations, and 36 social media sites about the nature of their education work in the country of origin, thus identifying 76 possible participants. From these 76 individuals, we received 65 responses to a second survey and found that many aspired to be engaged but were not yet engaged. Our final research sample included 28 individuals who were actively engaged in education work in their countries of origin: 
four individuals who identify as part of the Afghanistan diaspora, 12 of the Haiti diaspora, five of the South Sudan diaspora, and seven of the Zimbabwe diaspora. Most had migrated in their 20 s, and they ranged in age from early 20 s to 70 s. Seven were female and 20 male (see Table 1). Given the size of the sample, our analysis is not disaggregated by sex, class, education level, or age of migration, limiting our ability to determine whether and how these characteristics are relevant for diaspora's work.

We conducted the semi-structured interviews in-person at participants' homes, offices, and in public spaces (5); as well as virtually, via Skype (4) or telephone (18). The interviews lasted between one and three hours. The interviews were structured around participants' migration and educational histories, motivations for their education development work, factors that enable and constrain their work, and their goals and aspirations for education in their country of origin.

Our process for analysis was ongoing and iterative. First, after each interview, we listened to the recording and made notes about the participants' main ideas and verbatim quotes, beginning to identify the emerging themes within the interview. Thereafter, we developed a codebook with 139 codes within code families such as country of origin context; diaspora characteristics (e.g. migration history, language, education); the role of diaspora (e.g. as a 'source of money' or 'development actor', as perceived by participants or others); activities diaspora engage in related to education development (e.g. rebuilding schools, fundraising); and development processes (including enabling and constraining factors). Our codes represented both themes that we derived from the literature, such as responsibility to the country of origin, and themes that emerged from the interviews, such as schooling as hope for a different future. 
We then conducted consensus coding (Harry, Sturges, and Klingner 2005) on verbatim transcripts using the software Atlas.ti. For each interview, one author coded the interview and wrote a corresponding analytic memo about emerging patterns, and the other author reviewed the coding, re-coded where necessary, and added emerging analysis to the original memo. After all the interviews were coded, we undertook focused analysis across coded text related to the research questions. We analyzed these coded segments of text within individual interviews to understand individuals' experiences, across interviews with diaspora from the same countries to determine trends based on geography or sociopolitical circumstance, and finally across the entire sample to identify trends and nuances that emerged from cross-country comparisons. Through this analytical process, we developed a theory related to why and how diaspora engage in education development in their countries of origin based on our empirical data on their motivations for engagement, the nature of the activities they pursue, and the factors that enable and constrain their work. We shared a draft of the manuscript with all participants for their feedback and incorporated their corrections of fact and, in some cases, addition of details.

[Table 1 about here]

\section{Findings}

Across our sample, participants were motivated to engage in education development work by identities that kindled a sense of responsibility for communities, known and imagined, in the country of origin. Our participants' identities were often rooted in experiences of coming to understand their countries of origin through lenses of 
inequality, which inculcated responsibility oriented toward peace and a belief that education could transform conflict dynamics. Across the sample, participants felt situated to do this work well, emphasizing their embeddedness in the country of origin and the country of exile. We also found that diaspora positioned themselves as uniquely able to engage with often-unequal power dynamics in development work and interrogate country of origin colonial histories through the substance of their education work. They particularly did so in the ways they navigated their relationships with communities, outside actors, and authorities. Below, we analyze first why diaspora engage in education development in the ways they do and second how they negotiate their identities and embeddedness to do this work.

\section{Why Engage? Responsibility to Transform Opportunities through Education}

Most participants described their sense of responsibility for those still in the country of origin as developing first toward extended family and then toward known and imagined communities. Nedgine Paul Deroly explained that as a child, her identity was shaped by stories of her father's experiences as a teacher, school principal, and Episcopal priest in Haiti and knowing that her parents sent money for other children's school fees. Echoed across our dataset, a seminal experience for Deroly crystalized a sense of responsibility into activities for engagement. In her late teens, she traveled to visit a school in rural Haiti that her father had once led. On this trip, Deroly met a student who was "so proud of his school" despite its focus on memorizing lessons. She felt that he "deserved so much more." She explained that, at this moment, she understood why her family had prioritized supporting education in Haiti. In college, Deroly chose to study 
Haitian history, including the ways in which the Haitian education system, "perpetuated inequity," particularly focusing her senior thesis on changes to education in Haiti under the U.S. occupation of 1915-1934. She began to imagine what could be possible if education in the country were equitable. This vision prompted what she called "a sense of obligation" to contribute to a different kind of education than she saw being practiced in Haiti, especially by those "ignorant about our history and our culture." Deroly worked to connect the networks she had access to in both her country of origin and the U.S. and the assets of local communities in Haiti to focus on the inequities that drove her sense of responsibility; "teachers," she said, are "what's really going to change the outcomes." Deroly now leads what she described as "a local movement" called Anseye Pou Ayiti that recruits and equips a network of Haitian teacher-leaders to become the civic leaders throughout rural Haiti.

Across our dataset, we find that diaspora's motivations to engage in education development work stemmed from these deep-rooted identities and responsibilities to shift opportunities in the country of origin. John Gak connected the persistent lack of educational opportunities in South Sudan to re-ignition of conflict after the country's 2011 Independence. He provided school resources to South Sudanese refugee children in Uganda, envisioning that this imagined community in exile would become the leaders of South Sudan's future peace. At the time of the interview, Gak also hoped to build a vocational school in his home village, in the known community, where youth from ten tribes would be prepared to find and create jobs as well as learn about each other. His own education in what was then Sudan did not include this attention to building relationships across lines of difference, instead focused on military training exercises and 
sitting under a tree listening and reciting. His educational experiences in the United States led Gak to think differently, he said, about the role of education in addressing perceptions of difference and helping to create peace.

Like Deroly and Gak, most participants also found motivation to engage through their evolving understandings of colonial histories and inequalities in their countries of origin. Through perspectives shaped both inside and outside the country of origin, they described coming to understand how these histories affected education systems and education development work and yet how absent an historical perspective was from current education development. As Leonie Hermantin explained, "I'm just one of those nuts who actually take[s] our history very seriously and very personally," and in her education work, she seeks to "really show that my country of birth has given something to the world." Hermantin's education work in Haiti gave her a "chance to celebrate not destroying, but building." She saw her role as "helping to build local capacities for selfgoverning," in contrast to outsider "expert authority" so common to both colonial-era and contemporary education work. Hermantin believes that her unique position as an insider/outsider embedded in both Haiti and the U.S. enables her to integrate this understanding of Haiti's past in the creation of a locally-imagined future.

Like Hermantin, across the whole sample, participants located their sense of responsibility to engage in the new identities they developed through being embedded in multiple sites. Suraya Sadeed believed that only Afghans could contribute to decolonization of the education system, yet she developed the educational skills in curriculum development, and the resources to produce and disseminate it, from her Masters program in the United States and work with a U.S.-based NGO. She explained, 
"after 9/11, and after the intervention of the U.S., and NATO forces in Afghanistan, I refocused my efforts into what I believe can rescue that nation, and that is providing education, and innovative programs to new generations of Afghans." Sadeed explained that Afghans have become suspicious of hidden agendas in educational materials developed outside the country. Yet, "the Ministry of Education, unfortunately is a donordriven ministry" and makes decisions "that donors want," including taking textbooks and teacher training materials used in Sri Lanka and Minneapolis and translating them for use in Kabul. This kind of education development, she said, will not contribute to the peace she envisions:

Democracy is not one size fits all. It isn't. Because it just - it has to be homegrown. If every time that you want to import, or export democracy in another country, it's bound to fail... So what we did, we tried to make this [curriculum] as Afghan as possible ...

Despite her embeddedness in the United States, Sadeed perceived herself and found herself to be perceived as trustworthy and "homegrown" in her work in Afghanistan. This insider/outsider status allowed her to act on the responsibility she felt to design and implement curriculum that was substantively different than that forwarded under the prevalent donor-driven approaches she observed.

\section{How to Engage? Relationships to Transform Educational Opportunities}

A variety of factors enable and constrain the education work of diaspora, shaping the distance between their motivations and activities they are able to pursue. Some of these factors are contextual, including circumstances particular to individual countries of 
origin, such as corruption, the state of public infrastructure, or ongoing instability; they also include participants' needs to balance their education development work with jobs as technicians, teachers, social workers, professors, graduate students, fashion designers, accountants - and family responsibilities. However, the enabling and constraining factors that our participants emphasized in how they do this work were relational, including with authorities, communities, and outside actors.

Despite our selection of sites that were politically and institutionally conducive to development, diaspora's relationships with authorities in the countries of origin varied considerably by the role government played in providing education. In some cases, diaspora filled a role that authorities could or did not, providing education services to marginalized populations without engaging with government. In others, diaspora offered innovative education practices implemented within individual schools, sometimes in collaboration with government and with the aim of eventual uptake into national education systems. These varying relationships also showed different ways diaspora were able to couple their sense of responsibility for the country of origin with a claim to their rights to social and political participation in that country of origin. In many cases, a lack of government accountability—-to both citizens and diaspora — meant that participants were left to fulfill their sense of responsibility without state support.

In Afghanistan, for example, the education system is highly centralized. For diaspora, this centralization constrained independent action, as Sadeed described, yet it also enabled engagement with a large-scale public system. A strong relationship with the Ministry of Education (MOE) — and a willingness to accept the terms of engagement- 
helped Sakena Yacoobi and her organization meet the goal of providing teacher training at scale. She described the give-and-take within this relationship:

We do train their [MOE] teachers...20,000 teachers have been trained by AIL [Afghan Institute of Learning], and... most of them are public school teachers. We train them. And [the government] like[s] that, because they don't have to pay. We pay, and we train .... and they are enjoying the beauty of saying, '... we have teacher training; we did teacher training.' Are we okay with that? Yes. Why? Because our objective is to really bring the system [to quality education]. At the same time, the MOE in Afghanistan is not the only center of power. Kharoti observed needs in areas of Afghanistan that the MOE and donors were not focused on since, as he said, "All of the money that we had sent, that the international community sent, has gotten spent in the cities." With the aim of including rural Afghans in the imagined community, providing education that the government was not, he initiated conversations with the Taliban. He "spent three days in the mountains over there. Finally I was able to see them and I talked with them.” After lengthy discussions, eventually the Taliban members explained, “'We're not against education. If you want to do this go ahead...Go start working not one school, 20 schools. We cannot help you but you do it."” While Kharoti did not agree with Taliban positions, his status as an insider/outsider, and the relationships he was thus able to develop, allowed him to claim the right to undertake education development work in rural areas that the government was not attending to.

Despite a severe lack of capacity at the time of the interviews, South Sudan's MOE also strived to monitor education development work from a centralized position. When Angelo Marial wanted to build an early childhood center in his home community 
of about 5,000 people, the government took an active role by donating land. Millie Odong obtained government support to provide for furniture once she constructed the school building; yet ultimately the government was not able to, saying they "appreciate the work we are doing, ... [but] there is not a lot they can do, because they don't have the funding." Given fragility and conflict, the government of South Sudan struggled to fulfill responsibilities to its citizens and had limited accountability to diaspora. For our participants, this meant that their attempts to create educational opportunities in marginalized areas fell short, despite their ongoing sense of responsibility to act.

In contrast, the government of Zimbabwe exerted strict control over diaspora's work, constraining relationships between diaspora and authorities and also limiting the work itself. Japhet Zwana described two particularly challenging dynamics: the government's hostile attitude to education reform broadly, and the government's distrust of diaspora. Zwana explained that "there are people around [the President] who are very afraid of the intelligentsia, because it is the intelligentsia who would be best able to criticize them and put them into their place." This distrust made it difficult for diaspora to engage in education development. Zwana hoped these dynamics might shift so he could claim his rights to social and political participation through institution-building that would contribute to a more stable "Zimbabwe of tomorrow." Instead, he felt limited to creating opportunities for individuals by raising funds for poor students to attend university, with hopes that these individual investments might shift broader social inequalities over time.

For diaspora in Haiti, there were fewer restrictions on developing education projects, but also little coordination at the government level, making it difficult to affect 
system-wide change. As Deroly said, "You can go in and start a school tomorrow. There is just no oversight for that." Given the MOE's limited capacity, and even antagonism, many diaspora in Haiti elected to work independently from government. Romane Armand explained that "the Haitian government, yes, they want the Haitian Diaspora's money, and investment, but they don't want to involve them in the political process. They want their money, but don't want their voice, and their activism." Given the unregulated nature of education as a sector, diaspora found they could ignore government and focus expansion of opportunities in communities.

Despite diverse state-level factors that fostered different forms of education development and enabled different relationships with government authorities, participants universally described relationships of trust and reciprocity with communities in the country of origin as central to the kind of education development they pursued. Kerline Tofuri, for example, credited much of the success of her NGO in Haiti, Jou Nouvo, to her philosophy of "connecting... talking... listen[ing]." She worked with women who were illiterate and involved them in major decisions of the organization. "Yes, they cannot read or write," Tofuri explained, "but their experience is key." Tofuri did not tell people "come, here is what we are doing today," but rather asked, "here is what's happening, what do you think?" She credits her approach as allowing Jou Nuovo to grow from a program offering adult literacy classes to one that integrated health and microfinance with educational opportunities. Importantly, she noted, it differed from status quo development in that it did not follow short-term funding cycles but instead made a longterm commitment to the community. 
While these types of relationships in the country of origin were prevalent and tended to enable diaspora's work, in some cases trust was withheld from diaspora, constraining their efforts. Most of our participants were committed to work in their countries of origin because their identities were deeply connected to these places, but their views of themselves as insiders/outsiders embedded in two worlds did not always match the views of the people with whom they worked. According to Joseph Jok, for example, sometimes people who remained in South Sudan, especially those in the military or without education, did not feel that diaspora contributed to the country's liberation. In his view, "part of winning this war was not just only the war" but also advocacy with the U.S. government, a contribution that he could make given his multiple embeddedness but that some people he sought to work with in South Sudan did not recognize.

These questions of trust and type of authority shaped the relationships our participants had with outside actors as well, specifically donors and NGOs with no local or diaspora leadership. For some, these outside actors amplified and facilitated their work. Other participants remained skeptical about the motivations and possible impacts these outside actors could have, pointing in particular to unequal power dynamics and tensions of race and power.

Access to funding embodied these tensions between diaspora and outside actors. Jacques Parent, for example, felt that diaspora-led organizations were more effective in education development than organizations led by outsiders because they were "closer to the people, understand the people, and work with the people to get to a certain place." Despite these benefits, he noted that diaspora-led work was "the least funded, and it 
tend[ed] to get the least visibility." Jean Robert Anantua observed that to have access to the funds pouring into Haiti after the 2011 earthquake, "you have to be of a certain color...you will apply for these things, and then somehow, you don't get it, and the organization that can do it with the least amount of money, or amount of resources are not the ones who are getting it." With this reality in mind, Anantua made the decision to allow an outside NGO to take leadership of some of the programs he started in order to ensure their financial sustainability.

Despite convictions that they were in unique positions to use funding in ways that were responsive to community needs, many participants found they could not raise funding they needed in the absence of this ceding of ownership to outside actors. Similarly, Hermantin engaged outside NGOs as a way to extend from individual scholarships to founding a network of schools aimed at transforming education across Haiti. Yet she echoed how difficult partnerships with outsiders could be. She found herself in a "Catch-22 situation," she said: she could not achieve what she wanted without having to "bring white people in to do [it] for us," while at the same time trying to teach children in Haiti "to love themselves... in a culture that despises itself to some extent, because it's black, because it's poor."

Similarly, in South Sudan, Mayak Machar felt compelled to compromise his approach to education development when he was unable to marshal resources to act independently. After three years of trying unsuccessfully to build a school in an area of South Sudan that was overlooked by both government and outside actors, Machar instead decided to volunteer for an external NGO. He traveled within South Sudan to collect information that this NGO's staff seemed unwilling or unable to collect, enabled by his 
insider/outsider status to "wear whatever they [community members] wear or eat whatever kind of food they eat," and to provide insights that considered both what the NGO "should focus on and what they cannot work on." Yet Machar's relationship with the NGO was merely instrumental in ways that undermined his experiential knowledge of the kinds of education he believed could mitigate the conflicts he experienced as a young person in what was then Sudan. In their conflicted relationships with outside actors, diaspora revealed the ways education development privileges outsiders' engagement and approaches over diaspora's. Moreover, while seeking to engage in education development that was disruptive of these approaches, Hermantin and Machar found it necessary to engage with some of the very same structures of development that promoted them.

\section{Discussion}

Diaspora displaced from fragile and conflict-affected settings were motivated to engage in education development by identities rooted in a sense of responsibility for both known individuals in their countries of origin and for imagined communities. Experiences and embeddedness in countries of exile and countries of origin kindled in many a belief that education, especially that which engaged with historical inequalities and contemporary unequal opportunities, could transform underlying and persistent conflict dynamics. For this reason, many diaspora focused their engagement on the content of what children learn, often through teacher training and the development of curricula that encouraged critical thinking and upended narratives that privileged colonial and neocolonial power. Education that addresses this historical complexity and 
encourages local capacity contrasts with much current education development work that involves education models adapted from elsewhere by outsiders (Dale 1999, SteinerKhamsi and Waldow 2012). Our findings on why diaspora engage and the content of their engagement have broad implications for education development in FCS. Post-conflict education efforts are usually framed as reconstructive, implying that what existed before has been lost and efforts must focus on a new beginning. However, diaspora highlighted connections between historical and contemporary inequalities and the role of education in disrupting cycles of fragility and conflict.

The processes of how diaspora engage on these challenges are further instructive for policy and practice in education development. In all cases, diaspora emphasized the value of their embeddedness in countries of origin and exile to leverage local knowledge and relationships while also marshaling needed resources, human, financial, and experiential. Their power to utilize these resources varied across contexts and across relationships with authorities, communities, and outside actors. Across the sample, diaspora's relationships with communities were the strongest mechanism for action related to infusing ideas of conflict transformation into education initiatives. Relationships with authorities also facilitated their action, yet in divergent ways depending on the country. Our participants leveraged their embeddedness, and status, in countries of origin and exile to provide support to governments when acceptable and work around governments when they perceived them to stand in the way of shifting opportunity structures. In choosing not to leverage only their embeddedness in the U.S. to exert external authority or only their embeddedness in the country of origin to exert local 
authority, diaspora explicitly attempted to reimagine where power lies in education development.

Fluid navigation of insider/outsider roles was more challenging for diaspora in relationships with outside actors, and they found their agency constrained as they tried to engage with the power structures of status quo international development. Echoing other literature, these outside actors privileged external authority, especially as related to funding (Barnett 2013, Menashy 2017). As a result, our participants made compromises, partnering with external NGOs or outside, often white, organizational leaders who could provide this expert authority to garner financial sustainability. Our participants remained in less prestigious roles but ones in which they could continue to act true to their identities and on their felt responsibilities, maintaining authority over the substance of education, such as the content and curriculum of teacher training. Outside actors could use the findings of this study to engage in conversations about power in their relationships with diaspora, how this power shapes the education development to which they are jointly committed, and how they might work together on goals of increasing educational opportunities and mitigating conflict.

These findings also have implications for policies that could enable diaspora to apply the publicly-oriented and conflict transformation approaches that we document to education development in FCS more broadly. South Sudan is an interesting possible application of these implications. Chosen to be part of this study after the relative stability of Independence in 2011, our data collection also captured a relapse into widespread conflict by the end of 2014. Conflict and fragility are often cyclical, a dimension of education development with which diaspora in our sample were 
preoccupied in their choice of activities. In the event of cessation of acute conflict, the South Sudan MOE could take lessons from this study, facilitating diaspora-led education development that, through relationships, can leverage both their insider sense of responsibility to conflict transformation and their outsider access to resources.

National policies in most countries have long permitted and even encouraged diaspora to participate in development through the family/household sphere; the findings of this study suggest that policies would productively allow, and even support, diaspora to engage in systemic education development work within the spheres of known and imagined communities, seeking to create conflict-transformative education at scale. Outside actors, including donors and NGOs, could also contribute to this work by forming partnerships with diaspora that are attentive to power imbalances and actively seek to address them. This support would allow diaspora to engage in more sustainable education development work that seeks to act on the shared global challenges of reducing inequalities, widening opportunities, and mitigating conflict through education.

\section{Notes}

\footnotetext{
${ }^{1}$ All of our participants elected to be identified by their real names, secure in their legal positions within the U.S. and as leaders within their organizations. They also expressed the hope that this research would identify them and their organizations, as both a contribution to knowledge and to the on-going education development work to which every participant was committed.
} 
${ }^{2}$ We recognize that diaspora members might also marshal resources from the country of origin in ways that influence the country of exile, as a multi-directional flow of ideas and resources would suggest (Tsing 2005, Levitt and Jaworsky 2007). Given our focus on education development in the country of origin, we do not explore this idea further in this article.

${ }^{3}$ At this time, Sudan and South Sudan were considered together. 


\section{References}

Anderson, Benedict R. 1991. Imagined communities : reflections on the origin and spread of nationalism. Rev. and extended ed. London; New York: Verso.

Anderson, Bennedict R. 1998. "Long Distance Nationalism." In The Spectre of Comparisons: Nationalism, Southeast Asia and the World, edited by B. Anderson, 58-74. London: Verso.

Ball, Stephen, and Antonio Olmedo. 2011. "Globa Social Capitalism: using enterprise to solve the problems of the world." Citizenship: Social and Economics Education 10 (2 \& 3):83-90.

Barnett, Michael. 2013. "Humanitarian Governance." Annual Review of Political Science 16:379-398.

Bellino, Michelle J. 2017. Youth in postwar Guatemala : education and civic identity in transition, Rutgers series in childhood studies. New Brunswick, NJ: Rutgers University Press.

Bloemraad, Irene, and Alicia Sheares. 2017. "Understanding Membership in a World of Global Migration: (How) Does Citizenship Matter?" International Migration Review 51 (4):823-867. doi: 10.1111/imre.12354.

Brinkerhoff, Jennifer M. 2011. "Diasporas and conflict societies: Conflict entrepreneurs, competing interests or contributors to stability and development?" Conflict, Security \& Development 11 (2):115-143.

Brinkerhoff, Jennifer M. 2016. Institutional reform and diaspora entrepreneurs : the inbetween advantage. New York, NY: Oxford University Press.

Burde, Dana. 2014. Schools for conflict or for peace in Afghanistan. New York: Columbia University Press.

Carlson, W.L., Desir, A., Goetz, S., Hong, S., Jones, S., White, J. 2011. Haitian Diaspora \& Education Reform in Haiti: Challenges and Recommendations. Columbia University, School of International \& Public Affairs.

Christie, Pam. 2016. "Educational change in post-conflict contexts: reflections on the South African experience 20 years later." Globalisation, Societies and Education 14 (3):434-446. doi: 10.1080/14767724.2015.1121379.

Cohen, Jeffrey H. 2011. "Migration, Remittances, and Household Strategies." Annual Review of Anthropology 40:103-114.

Dale, Roger. 1999. "Specifying globalization effects on national policy: a focus on the mechanisms." Journal of Education Policy 14 (1):1-17. doi: 10.1080/026809399286468.

Davies, Lynn. 2011. "Can Education Interrupt Fragility? Towards the Resilient and Adaptable State." In Educating Children in Conflict Zones: Research, Policy, and Practice for Systemic Change (A Tribute to Jackie Kirk), edited by Karen Mundy and Sarah Dryden-Peterson, 33-48. New York: Teachers College Press.

Duffield, Mark. 2001. Global Governance and the New Wars: The Merging of Development and Security. London: Zed Books.

Edwards, Alejandra Cox, and Manuelita Ureta. 2003. "International migration, remittances, and schooling: evidence from El Salvador." Journal of Development Economics 72 (2):429. doi: 10.1016/S0304-3878(03)00115-9. 
Faist, Thomas, and Margit Fauser. 2011. "The Migration-Development Nexus: Toward a Transnational Perspective." In The migration-development nexus : a transnational perspective, edited by Thomas Faist, Margit Fauser and Peter Kivisto, 1-28. New York: Palgrave Macmillan.

Fox, Jonathan. 2005. "Unpacking "Transnational Citizenship"." Annual Review of Political Science 8:171-201.

Gambino, Christine P., Edward N. Trevelyan, and John Thomas Fitzwater. 2014. The Foreign-Born Population From Africa: 2008-2012. Washington, DC: U.S. Census Bureau.

Glick Schiller, Nina. 2011. "A Global Perspective on Migration and Development." In The migration-development nexus : a transnational perspective, edited by Thomas Faist, Margit Fauser and Peter Kivisto, 29-56. New York: Palgrave Macmillan.

Harry, Beth, Keith M. Sturges, and Janette K. Klingner. 2005. "Mapping the Process: An Exemplar of Process and Challenge in Grounded Theory Analysis." Educational Researcher 34 (2):3-13.

Horst, Cindy. 2006. Transnational Nomads. Oxford: Berghahn.

Horst, Cindy. 2013. "The Depoliticisation of Diasporas from the Horn of Africa: From Refugees to Transnational Aid Workers." African Studies 72 (2):228-245. doi: 10.1080/00020184.2013.812881.

Hovil, Lucy. 2016. Refugees, conflict and the search for belonging. 1st edition. ed. Cham, NY: Springer International Pub.

Iskander, Natasha N. 2010. Creative state : forty years of migration and development policy in Morocco and Mexico. Ithaca: ILR Press.

Karabegović, Dženeta. 2017. "Aiming for transitional justice? Diaspora mobilisation for youth and education in Bosnia and Herzegovina." Journal of Ethnic and Migration Studies:1-16. doi: 10.1080/1369183x.2017.1354165.

Khurshid, Ayesha. 2012. "A Transnational Community of Pakistani Muslim Women: Narratives of Rights, Honor, and Wisdom in a Women's Education Project." Anthropology \& Education Quarterly 43 (3):235-252. doi: 10.1111/j.15481492.2012.01176.x.

King, Elisabeth. 2013. A Critical Review of Community-Driven Development Programmes in Conflict-Affected Contexts. London: Department for International Development (DFID).

King, Elisabeth. 2014. From classrooms to conflict in Rwanda. New York: Cambridge University Press. text.

Lampert, Ben. 2012. "Diaspora and Development? London-based Nigerian Organisations and the Transnational Politics of Socio-economic Status and Gender." Development Policy Review 30 (2):149-167. doi: 10.1111/j.14677679.2012.00569.x.

Levitt, Peggy. 1998. "Social Remittances: Migration Driven Local-Level Forms of Cultural Diffusion." International Migration Review 32 (4):926-948.

Levitt, Peggy, and B. Nadya Jaworsky. 2007. "Transnational Migration Studies: Past Developments and Future Trends." Annual Review of Sociology 33:129-156. 
Lu, Yao, and Donald J. Treiman. 2011. "Migration, Remittances and Educational Stratification among Blacks in Apartheid and Post-Apartheid South Africa." Social Forces 89 (4):1119-1143.

Lyons, Terrence. 2007. "Conflict-generated diasporas and transnational politics in Ethiopia." Conflict, Security \& Development 7 (4):529-549.

McGregor, JoAnn, and Dominic Pasura. 2010. "Diasporic Repositioning and the Politics of Re-engagement: Developmentalising Zimbabwe's Diaspora?" The Round Table 99 (411):687-703. doi: 10.1080/00358533.2010.530413.

Menashy, Francine. 2017. "Multi-stakeholder aid to education: power in the context of partnership." Globalisation, Societies and Education:1-14. doi: 10.1080/14767724.2017.1356702.

Mügge, Liza. 2012. "Dual Nationality and Transnational Politics." Journal of Ethnic \& Migration Studies 38 (1):1-19. doi: 10.1080/1369183X.2012.640003.

Nielsen, Tjai M., and Liesl Riddle. 2009. "Investing in Peace: The Motivational Dynamics of Diaspora Investment in Post-Conflict Economies." Journal of Business Ethics 89 (4):435-448. doi: 10.1007/s10551-010-0399-z.

Novelli, Mario. 2016. "Capital, inequality and education in conflict-affected contexts." British Journal of Sociology of Education 37 (6):848-860. doi: 10.1080/01425692.2016.1165087.

Novelli, Mario, and Sean Higgins. 2017. "The violence of peace and the role of education: insights from Sierra Leone." Compare: A Journal of Comparative and International Education 47 (1):32-45. doi: 10.1080/03057925.2015.1119650.

OECD-DAC. 2007. Principles for Good International Engagement in Fragile States and Situations. Paris: OECD.

Ong, Aihwa. 1999. Flexible Citizenship: The Cultural Logics of Transnationality. Durham, NC: Duke University Press.

Pasura, Dominic. 2012. "A Fractured Transnational Diaspora: The Case of Zimbabweans in Britain." International Migration 50 (1):143-161. doi: 10.1111/j.14682435.2010.00675.x.

Paulson, Julia. 2015. "'Whether and How?" History Education about Recent and Ongoing Conflict: A Review of Reseach." Journal on Education in Emergencies $1(1): 14-47$.

Piper, Benjamin. 2016. "International Education is a Broken Field: Can ubuntu education bring solutions?" International Review of Education. doi: DOI 10.1007/s11159016-9544-y.

Portes, Alejandro, and Julia Sensenbrenner. 2003. "Embeddedness and Immigration: Notes on the Social Determinants of Economic Action." American Journal of Sociology 98 (6):1320-1350.

Pswarayi, Lloyd, and Tony Reeler. 2012. 'Fragility' and education in Zimbabwe: Assessing the impact of violence on education.: Research and advocacy unit.

Purkayastha, Bandana. 2010. "Interrogating Intersectionality: Contemporary Globalisation and Racialised Gendering in the Lives of Highly Educated South Asian Americans and their Children." Journal of Intercultural Studies 31 (1):2947. doi: 10.1080/07256860903477696. 
Sarabia, Heidy. 2011. "Organizing 'Below and to the Left': Differences in the Citizenship and Transnational Practices of Two Zapatista Groups." Sociological Forum 26 (2):356-380. doi: 10.1111/j.1573-7861.2011.01244.x.

Sen, Amartya Kumar. 1999. Development as freedom. New York: Oxford University Press.

Smith, Michael Peter. 2005. "Transnational Urbanism Revisited." Journal of Ethnic \& Migration Studies 31 (2):235-244. doi: 10.1080/1369183042000339909.

Sommers, Marc. 2004. Co-ordinating education during emergencies and reconstruction: challenges and responsibilities. Paris: International Institute for Educational Planning.

Srivastava, Prachi, and Su-Ann Oh. 2010. "Private foundations, philanthropy, and partnership in education and development: mapping the terrain." International Journal of Educational Development 30 (5):460-471. doi: https://doi.org/10.1016/j.ijedudev.2010.04.002.

Steiner-Khamsi, Gita, and Florian Waldow. 2012. World Yearbook of Education 2012 : Policy Borrowing and Lending in Education. London.

Takayama, Keith, Arathi Sriprakash, and Raewyn Connell. 2017. "Toward a Postcolonial Comparative and International Education." Comparative Education Review 61.

Thyne, Clayton. 2006. "ABC's, 123's, and the Golden Rule: The Pacifying Effect of Education on Civil War, 1980-1999." International Studies Quarterly 50 (4):733754.

Tsing, Anna Lowenhaupt. 2005. Friction : an ethnography of global connection. Princeton, N.J.: Princeton University Press.

U.S. Census Bureau. 2014. "Place of Birth for the Foreign-Born Population in the United States, 2014 American Community Survey." U.S. Census Bureau, accessed 13 August. https://factfinder.census.gov/faces/nav/jsf/pages/index.xhtml.

UNHCR, and Global Monitoring Report. 2016. No more excuses: Provide education to all forcibly displaced people. Paris: UNESCO.

UNICEF. 2017. Education: South Sudan.

United Nations General Assembly. 2016. New York Declaration for Refugees and Migrants. New York: United Nations.

USAID. 2016. Haiti Education Fact Sheet. In Education Fact Sheet.

USAID. 2017. Education Fact Sheet Afghanistan. In Education Fact Sheet: USAID. Van Hear, Nicholas. 2011. "Diasporas, Recovery and Development in Conflict-ridden Societies." In The migration-development nexus : a transnational perspective, edited by Thomas Faist, Margit Fauser and Peter Kivisto, 85-103. New York: Palgrave Macmillan.

Van Hear, Nicholas. 2014a. "Refugees, Diasporas, and Transnationalism." In The Oxford handbook of refugee and forced migration studies, edited by Elena FiddianQasmiyeh, Gil Loescher, Katy Long and Nando Sigona, xxviii, 747 pages. Oxford, United Kingdom: Oxford University Press.

Van Hear, Nicholas. 2014b. "Refugees, Diasporas, and Transnationalism." In The Oxford Handbook of Refugee and Forced Migration Studies, edited by Gil Loescher Elena Fiddian-Qasmiyeh, Katy Long, and Nando Sigona, 176-187. Oxford: Oxford University Press. 
Watkins, S.C., Swidler, A., Hannan, T. 2012. "Outsourcing Social Transformation: Development NGOs as Organizations." Annual Review of Sociology 38:285-315.

Wood, E.J. 2008. "The Social Processes of Civil War: The Wartime Transformation of Social Networks." Annual Review of Political Science (11):539-561.

World Bank. 2011. World Development Report: Conflict, Security, and Development. Washington, DC: World Bank.

Wyeth, V. . 2012. "Knights in Fragile Armor: The Rise of the "G7+"." Global Governance: A Review of Multilateralism and International Organizations 18:712. 